has provided some useful information for research students who are preparing their material for publication. The first part of the pamphlet deals with the preparation of a thesis submitted for higher degrees in education and includes useful sections on the length and form of the thesis, the general pattern, outline of the research, statement of the problem, review of the pertinent literature, descriptions of the design of the experiment, description of the techniques, statement of the results, interpretation and discussion of the results, how to summarize the conclusions and the setting out of the bibliography. In the second part of the booklet Wiseman examines how a paper should be prepared for publication and deals with such topics as preliminary planning, the form of typescript to be used, the use of tables and diagrams, the question of proofs, the taking of off-prints and typography. The whole pamphlet is weil written and would be of value not only to research students in education but also to those who have investigations to report in any academic study.

\section{Petroleum Films Bureau}

The Petroleum Films Bureau has recently published its 1952 list of $35-\mathrm{mm}$. and 16- $\mathrm{mm}$. documentary and instructional films. It contains certain features not found in the previous 1951 list, and included among the new films are "Oil for the 20th Century", "The Persian Oil Dispute", "Grangemouth Project", "Air Parade", "Highlights of Farnborough, 1951", "Model Flight", "Festival Log Book", "XXIst Monte-Carlo Rally 1951", "An Introduction to the Heat Engine", "Machining of Metals", "The Gas Turbine goes to Sea", "Weed Control", and also some additions to the film magazine series. All 16-mm. films are printed on 'non-flam' stock; the $35-\mathrm{mm}$. films are on 'flam' stock. As previously, films are available free of charge (return postage to be paid) to educational institutions, societies, clubs and the like, and application should be made to the Bureau at 29 New Bond Street, London, W.1.

\section{Colonial Service : Recent Appointments}

THE following appointments have recently been made in the Colonial Service : E. G. Harmer (senior produce officer, Department of Marketing and Exports, Nigeria), principal produce officer, Department of Marketing and Exports, Nigeria; F. A. Squire (entomologist, Sierra Leone), director of tsetse control, Gold Coast; R. M. Arnold (veterinary investigation officer, Jamaica), deputy director (livestock), Jamaica ; K. D. S. Macowan (senior veterinary officer, Kenya), deputy director of veterinary services, Kenya ; E. P. Rice (senior veterinary officer, Kenya), assistant director of veterinary services, Kenya; J. G. Ross (veterinary officer, Cyprus), veterinary officer, Uganda; Dr. F. D. Ommanney (principal scientific officer, East African Marine Fisheries), director of the Regional Marine Fisheries Research Station, Singapore ; D. R. Brewin and B. R. 'Tarr, agricultural officers, Tanganyika; E. L. Drake, entomologist, Nyasaland; A. D. S. Duff, plant pathologist, Kenya ; L. J. Hart, agricultural chemist, Tanganyika; R. J. Harvie, agricultural officer, Uganda; W. Hirst, botanist (plant pathologist), Uganda; O. T. Roberts and R. A. Sands, agricultural officers, Kenya; A. L. Wharton, plant pathologist, West African Cocoa Research Institute, Gold Coast ; A: J. Radford, government chemist, Mauritius; B. Douglas, assistant conservator of forests, Northern Rhodesia : J. A. Seymour, geologist, - Somaliland
Protectorate; W. Hardie, veterinary officer, Fiji ; B. M. Brown, meteorologist, Nigeria ; L. J. Dyke, field officer (research), Mineral Resources, Uganda; F. C. F. Wickery, technical assistant, Mineral Resources (Research) Committee, Uganda.

\section{Announcements}

Prof. P. A. M. Dirac, Lucasian professor of mathematics in the University of Cambridge, has been awarded the Planck Medal for 1952. This Medal is awarded annually by the Association of German Physics Institutes for special accomplishments in theoretical physics which have a connexion with Planck's work. The Medal was founded some twenty years ago and the first recipient was Planck himself. The award is announced to the recipient each year on Planck's birthday, April 23, and the presentation is made at the autumn meeting of the Association of German Physics Institutes.

A DINNER to mark the centenary of Sir William Ramsay (see Nature, October 4, p. 554) will be held at University College, London, on October 15. The guest of honour will be H.R.H. The Duke of Edinburgh.

AN exhibition illustrating the work on logic of W. Stanley Jevons has been arranged in the Christie Library of the University of Manchester, and will be open during October 15-31. It includes Jevons's original logical machine, loaned by the History of Science Museum, Oxford, and more modern machines.

ThE Committee of Privy Council for Agricultural Research and Nature Conservation has re-appointed Prof. G. R. Cameron, Sir James Turner and Sir James Scott Watson to membership of the Agricultural Research Council for a further term. The Committee has also appointed, after consultation with the President of the Royal Society, Prof. E. J. Maskell, Mason professor of botany in the University of Birmingham, Prof. P. B. Medawar, Jodrell professor of zoology and comparative anatomy in the University of London, Prof. L. P. Pugh, professor of veterinary medicine in the University of Cambridge, and Prof. J. S. Young, professor of pathology in the University of Aberdeen, to fill the vacancies caused by the death of Prof. F. T. Brooks and the retirement from the Council of Prof. A. C. Chibnall, Sir Thomas Dalling, Sir Alan Drury and Dr. Joseph F. Duncan.

THE Manson Lectures for 1952 of the Royal Institute of Philosophy, on the general topic, "Mind and its Place in Nature", will be given at University Hall, 14 Gordon Square, London, W.C.1, on Fridays, at 5.30 p.m., beginning October 17 . The speakers will be Prof. J. Z. Young, Dr. C. G. Phillips, Dr. Macdonald Critchley, Dr. O. L. Zangwill, Prof. A. W. P. Wolters and Dr. A. C. Ewing.

THE Printing, Packaging and Allied Trades Research Association is holding a conference and exhibition at the Jackson Hall, Westgate Street, Cardiff, on October 27, at which there will be two sessions, on "Research and the Printer" and a "Brains Trust", respectively. The whole programme will be repeated at the Grand Hotel, Bristol, on October 29, where in addition there will be a technical discussion on October 30 and a further viewing of the exhibition. Further information can be obtained from the Association at Patra House, Randalls Road, Leatherhead, Surrey 